\title{
Biofilm and Multimedia Filtration for Rainwater Treatment
}

\author{
Rasima Abdul Rasid \\ Department of Chemical and Process Engineering, Faculty of Engineering \\ Universiti Kebangsaan Malaysia (UKM) \\ 43650 UKM Bangi, Malaysia \\ E-mail: rasimarasid@yahoo.com \\ Rakmi Abdul Rahman \\ Department of Chemical and Process Engineering, Faculty of Engineering \\ Universiti Kebangsaan Malaysia (UKM) \\ 43650 UKM Bangi, Malaysia \\ E-mail: rakmi@vlsi.eng.ukm.my \\ Rasina Abdul Rasid \\ Institute of Aquaculture, University of Stirling \\ FK9 4LA Scotland, United Kingdom \\ E-mail: r.b.a.rasid@stir.ac.uk
}

This research is financed by Asian Regional Research Program me on Environmental Technology (ARRPET II) and Ministry of Science, Technology and Environment, Malaysia (IRPA 08-02-02-0003 EA094 Grant).

\begin{abstract}
This study of biofilm column and multimedia filtration which consist of granular activated carbon (GAC)-biofilm configured up-flow fluidized expanded bed (UFEB) reactor and slow down-flow packed sand bed reactor. To empathize the effectiveness of the multimedia filter, the characteristics of the process in removing the recalcitrant organic compound were investigated. This multimedia filter was run in fluidized expanded bed with hydraulic retention time (HRT) ranged from 2-8 hours. The multimedia filter showed efficient performance with a removable of $75.49 \%$ of iron $\left(\mathrm{Fe}_{2}{ }^{+}\right)$and sulphate $\left(\mathrm{SO}_{4}{ }^{2-}\right) 62.10 \%$ was removed. More than $92.59 \%$ of COD removal was achieved in this study. Besides that, this experiment also shows the good performance of ammonia $\left(\mathrm{NH}_{4}^{+}\right)$, nitrate $\left(\mathrm{NO}_{3}^{-}\right)$and nitrite $\left(\mathrm{NO}_{2}^{-}\right)$ removals, which ammonia removal is $45.16 \%$, nitrate removal range from $51.76 \%$ to $82.98 \%$ and nitrite removal up to $65.93 \%$ respectively without replenishment of external carbon source. The biomass attached to the GAC was originated from the rainwater range between $177 \mathrm{mgl}^{-1}$ and $3886 \mathrm{mgl}^{-1}$.
\end{abstract}

Keywords: Biofilm column, Multimedia filtration, Fluidized expanded bed, Recalcitrant organics

\section{Introduction}

Rainwater harvesting (RWH) is an option which has been adopted in many parts of the world where conventional water supply systems have failed to meet the needs of the people. As demand for water increased whiles the water resources is limited, there is a growing awareness to collect rainfall and make more efficient use of the rainwater. Rainwater harvesting is most applicable where other sources of water are either not available or are too expensive. Rainwater collection and utilization schemes are said to be optimal when implemented in conjunction with water demand management as well as measures to enhance aquifer recharge (Session reports 1999).

In general, the quality of roof runoff is acceptable to supply low quality domestic uses. Pollutant additions to roof runoff include organic matter, inert solids, faecal deposits from animals and birds, trace amounts of some metals, and even complex organic compounds (Forster 1991). These form the essential nutrients for growth of bacteria (WRC 1993). Factors such as type of roof material, antecedent dry period (atmospheric deposition) and surrounding environmental conditions (proximity of strong sources, such as motorways or industrial areas) have been shown to influence concentrations of heavy metals in roof runoff (Yaziz et al. 1989; Thomas \& Greene, 1993; Forster 1996). 
Biological growth may occur within the filter which is known as biofilm. The term, biofilm refers to the development of microbial communities on submerged surfaces in aqueous environments (Characklis \& Marshall, 1990). A biofilms consists of cells immobilized at a substratum and frequently embedded in an organic polymer matrix of microbial origin. Biofilm generally is very adsorptive and porous ( $>95 \%$ water) structure. This bioremoval of heavy metal processes generally fall into three categories: biosorption of metal ions onto the surface of microorganisms, chemical transformation of metal ions and intracellular uptake of metal ions by microorganisms (Dursun et al. 2003). Biofilms observed in many waters consist of a large fraction of adsorbed and entrapped materials such as solutes and inorganic particles. (e.g., clay, silt). (William \& Marcelo 2003).

\section{Methods and Materials}

A research for rainfall collection system for household conditions has been outlined in Figure 1. This research is located at Bangi, about $20 \mathrm{~km}$ from the main city Kuala Lumpur. Runoff water from the roof surface is first flow into storage tank 1 in the ground level through a pre-filter and a second filter. Then the rainwater will be stored in a second tank after a third filter, which is placed at the pipe connecting from the first tank to the second tank. Rainwater was continuously fed to the reactor A by up flow mode and into reactor B by down flow mode with varying fluid velocity by a variable speed peristaltic pump, at the inlet flow rate, Q of 24 96 Lday ${ }^{-1}$.

The multimedia filter was initially operated at 12 hours HRT for 2 months, and then changed to operated at different hydraulic retention time (HRT) ranged from 2 to 8 hours. Figure 1 shows the plant schematic and reactor configuration.

Reactor A is initially filled with about $17 \mathrm{~cm}$ height of granular activated carbon (GAC). This reactor was packed with GAC particles of $0.25-2.00 \mathrm{~mm}$ particle size, with mean diameter of $1.30 \mathrm{~mm}$ and particle density of $1200 \mathrm{kgm}^{-3}$. GAC was used as adsorbent and biomass support media. 1000 pieces of plastic media was placed in reactor A as filter media. The frame of the multimedia reactors is made of arc halite. Table 1 shows the design information for each reactor.

The reactor B is filled with gravel, coarse and fine sand bed. The fine sand bed is $0.125-0.25 \mathrm{~mm}$ in sizes were used as to remove the floc (dirt particles) from the rainwater. Water was drained from the base of the filter through $0.3 \mathrm{~cm}$ wide perforate on the top surface of the $20 \mathrm{~cm}$ PVC pipe to the opening.

\section{Results and Discussion}

Multimedia filter has been operating for 390 days, demonstrating that removal of organic ions and heavy metals can be maintained in the multimedia filter with GAC as support media, for extensive time periods without replenishment of external carbon source. The biofilm in the multimedia filter in this study was able to remove iron $\left(\mathrm{Fe}_{2}{ }^{+}\right)$up to $75.49 \%$ with an average concentration in the effluent is $0.01 \pm 0.01 \mathrm{mg} / \mathrm{L}$. The COD average concentration in the rainwater is $7.33 \pm 0.34 \mathrm{mg} / \mathrm{L}$ while the COD concentration in the effluent is $2.6 \pm 3.2 \mathrm{mg} / \mathrm{L}$. Overall the COD reduction is in the range of $37.20 \% \sim 92.59 \%$. (Refer to Figure 2)

Sulphate $\left(\mathrm{SO}_{4}{ }^{2-}\right)$ removal percentage average was $35.09 \%$. The average concentration of $\mathrm{SO}_{4}{ }^{2-}$ in the effluent is $0.7 \pm$ $0.6 \mathrm{mg} / \mathrm{L}$ while the percentage reduction range is between $17.30 \%$ and $62.10 \%$. On the other hand, the average concentration of ammonia $\left(\mathrm{NH}_{4}{ }^{+}\right)$in the effluent is $0.022 \pm 0.010 \mathrm{mg} / \mathrm{L}$. Percentage reduction of $\mathrm{NH}_{4}{ }^{+}$overall was $45.16 \%$ accomplished. (Refer to Figure 3)

Nitrate $\left(\mathrm{NO}_{3}{ }^{-)}\right.$removal within the system was apparent from the beginning of the experiment and although there was some variation in the removal efficiency, the removal percentage range between $51.76 \%$ and $82.98 \%$ with an average concentration is $1.0 \pm 0.9 \mathrm{mg} / \mathrm{L}$ in the effluent. Moreover, the average concentration of nitrite $\left(\mathrm{NO}_{2}^{-}\right)$is $0.007 \pm 0.003$ $\mathrm{mg} / \mathrm{L}$ while the percentage reduction in the range of $2.48 \% \sim 65.93 \%$ was achieved. (Refer to Figure 4)

The biomass attached to the GAC was originated from the rainwater. Figure 6 shows the significant variations of biomass concentration in reactor in the experimental runs. After changing to expanded bed operation, there was a significant loss of biomass, decreasing from $3886 \mathrm{mg} / \mathrm{L}$ to around $177 \mathrm{mg} / \mathrm{L}$. Characklis (1973) reported that high velocity would retard the primary biofilm formation. (Refer to Figure 5)

\section{Conclusion}

Based on the results of this study, it has shown that the biofilm and multimedia filters are effective, since the filtration media combine the filtration properties of several materials. It has shown in the results that with a biofilm attached to the GAC surface which consists of bacteria held in an excreted polysaccharide coating, the uptake rate and quantity of metal ions extracted from the samples can be significantly increased. This system is ideally suit from economic point of view for locations being a low cost technology requiring low initial expenditure, zero power need, no maintenance cost and self dependent operation even for areas where there is normal seasonal rains.

\section{References}

Dursun, A. Y., Uslu, G., Tepe, O., Cuci, Y., Ekiz, H. I. A. (2003). Comparative investigation on the bioaccumulation of heavy metal ions by growing Rhizopus arrhizus and Aspergillus niger. Biochemical Engineering Journal, 15, 87-92. 
Characklis, W.G. \& Marshall, K.C. (1990). Biofilms. Wiley, New York.

Forster J. (1996). Patterns of roof runoff contamination and their potential implications on practice and regulation of treatment and local infiltration. Water Science and Technology, 33(6): 39-48.

Forster J. (1991). Roof runoff pollution. In: Grottker M, Schilling W, editors. Proceedings of Second European Junior Scientist Workshop, Kastienbaum, Switzerland. pp. 145-58.

Session reports. (1999). In: Proceedings of the International Symposium on Efficient Water Use in Urban Areas, pp. 7 -25 .

Thomas PR, Greene GR. (1993). Rainwater quality from different roof catchments. Water Science and Technology, 28(3-5): 291-7.

Water Research Commission (WRC). (1993). Guidelines on the cost effectiveness of rural water supply and sanitation projects. Water Research Commission Report No. 231/1/93, Pretoria.

William, Z. \& Marcelo, D. (2003). Rainwater chemistry at the summit and southern flank of the Itatiaia massif, Southeastern Brazil. Environmental Pollution, 129: 63-68.

Yaziz MI, Gunting H, Sapari N, Ghazali AW. (1989). Variations in rainwater quality from roof catchments, Water Research, 23(6):761-5.

Table 1. Design information for Reactor A and Reactor B

\begin{tabular}{lcc}
\hline & Reaktor A & Reaktor B \\
\hline Height, cm & 110 & 80 \\
Internal diameter, cm & 15 & 12 \\
Reactor volume, $\mathrm{L}$ & 8 & 6 \\
Support media & $\begin{array}{c}\text { Granular activated carbon } \\
(\text { GAC) \& Plastic media }\end{array}$ & Gravel, Coarse and Fine Sand \\
\hline
\end{tabular}

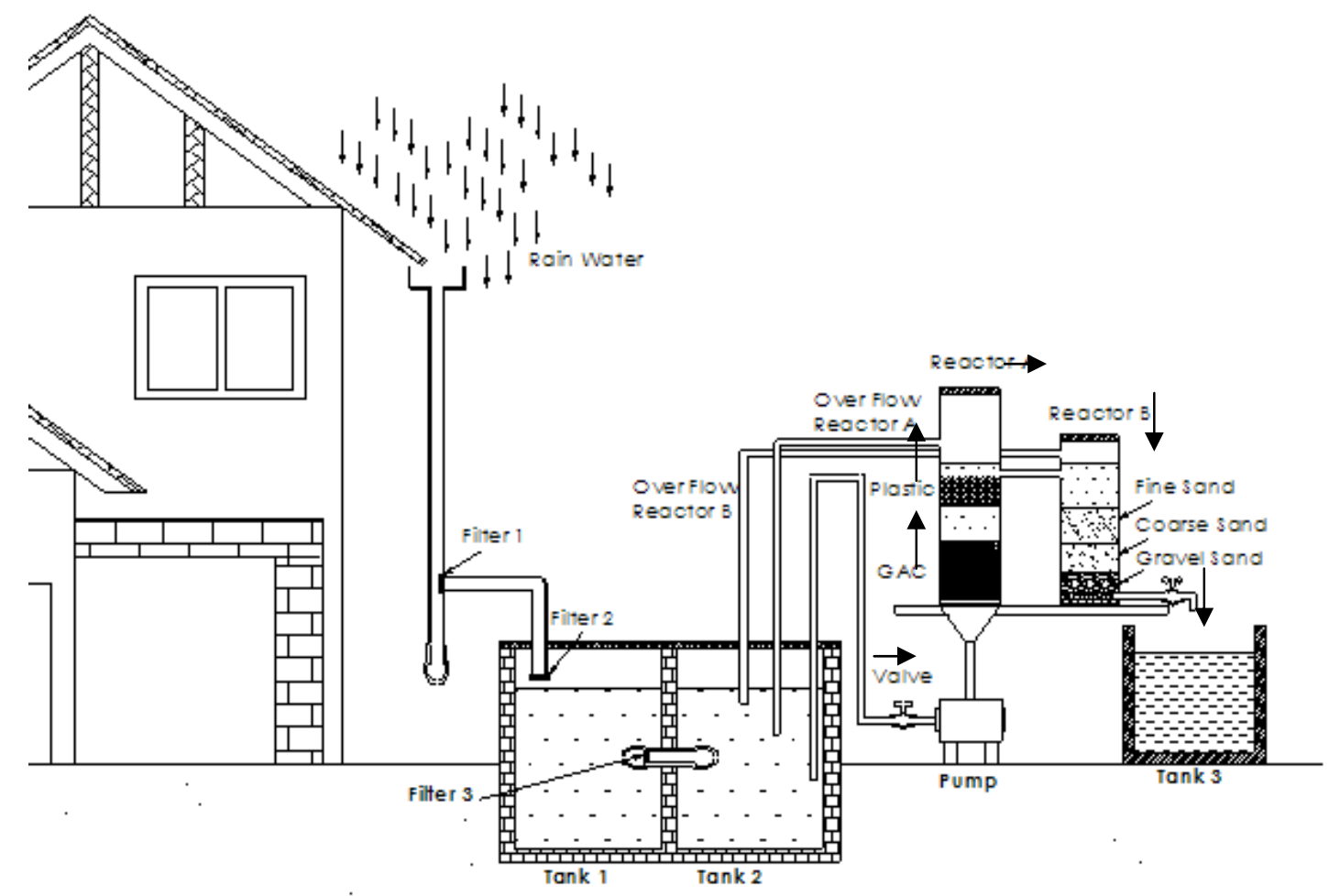

Figure 1. Plant schematic and Reactor Configuration 

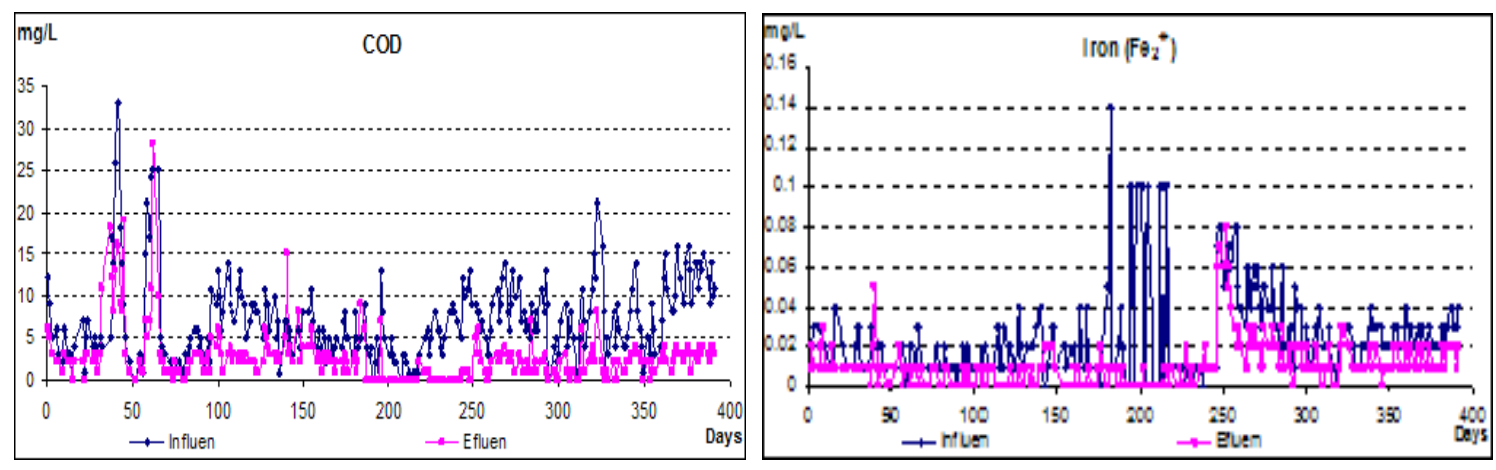

Figure 2. COD and Iron $\left(\mathrm{Fe}_{2}{ }^{+}\right)$concentration in rainwater and after filtration
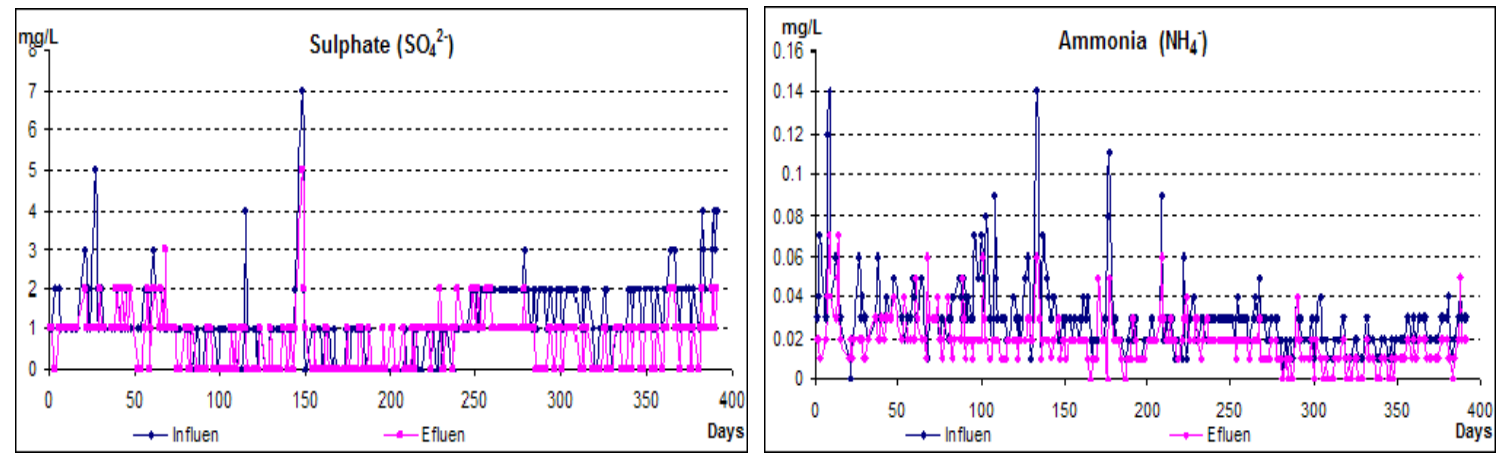

Figure 3. Sulphate $\left(\mathrm{SO}_{4}{ }^{2-}\right)$ and Ammonia $\left(\mathrm{NH}_{4}{ }^{+}\right)$concentration in rainwater and after filtration
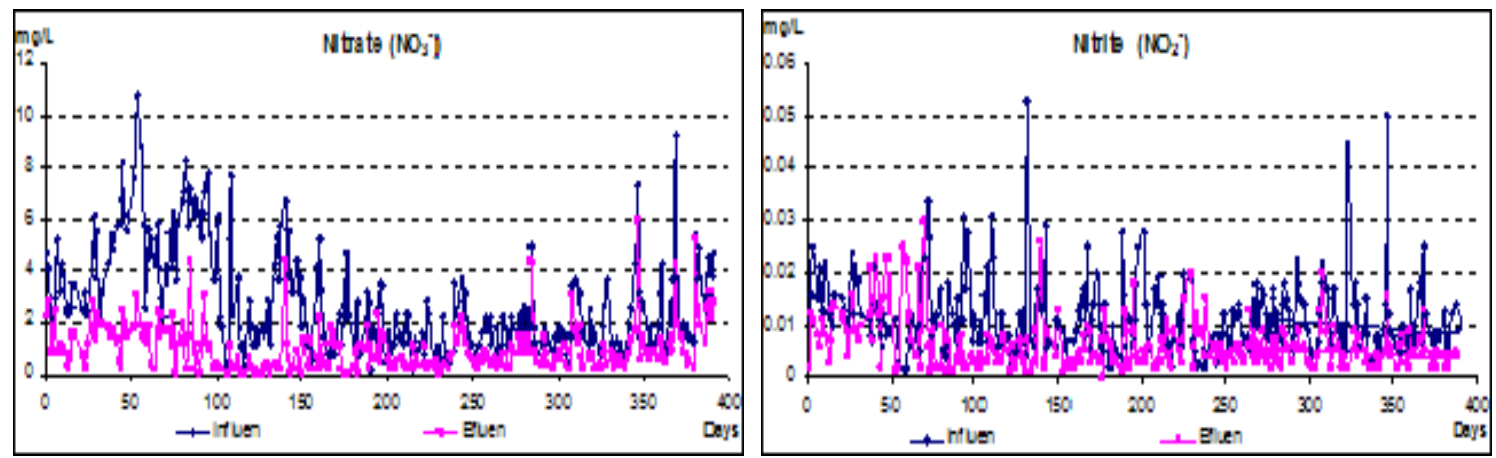

Figure 4. Nitrate $\left(\mathrm{NO}_{3}^{-}\right)$and Nitrite $\left(\mathrm{NO}_{2}^{-}\right)$concentration in rainwater and after filtration

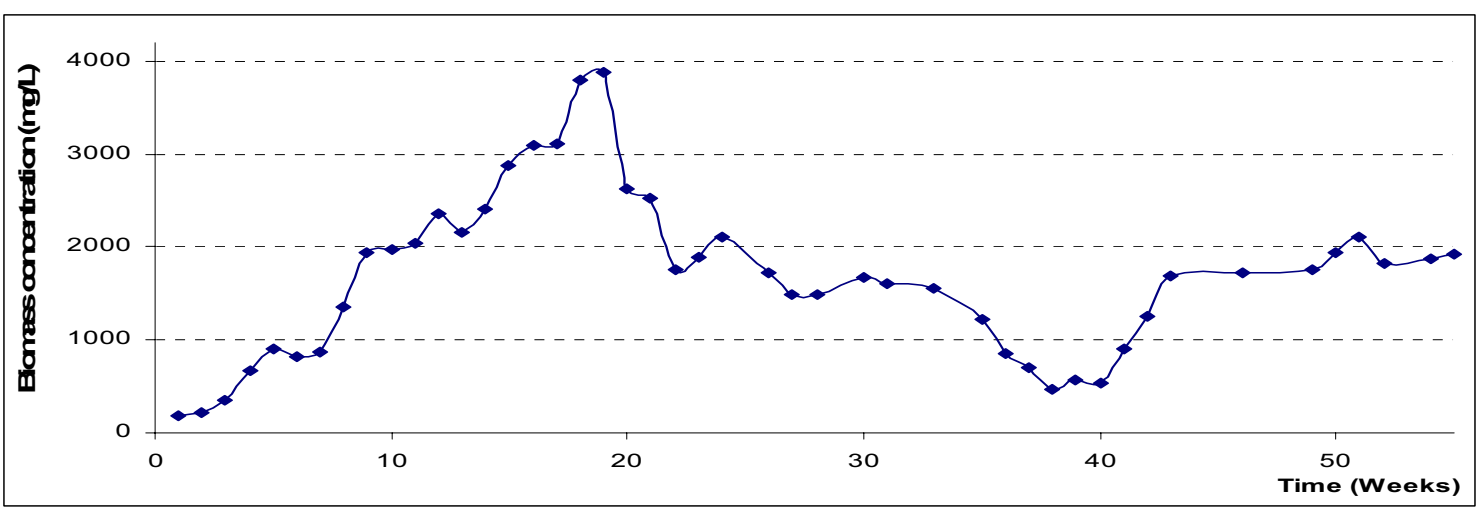

Figure 5. Biomass concentrations in GAC biofilter 